\title{
POLYSACCHARIDES OF SOME INVERTEBRATES OF THE SEA OF JAPAN
}

Yu. S. Ovodov, R. P. Gorshkova, S. V. Tomshich, and M. N. Adamenko

Khimiya Prirodnykh Soedinenii, Vol. 5, No. 2, pp. 116, 1969

There is a limited amount of information on the polysaccharides of marine invertebrates [1,2]. From widely distributed invertebrates of the Sea of Japan (Chaetopterus variopedatus, Crenomytilus grayanus, Glycymeris yessoensis, Patinopecten yessoensis, Chlamys swifti, Asterias amurensis, Tethyum aurantium) after treatment with acetone we have isolated lypopolysaccharide-protein complexes by various methods of extraction (45\% aqueous phenol [3], 32\% or $5 \%$ TCA [4], $0.01 \mathrm{~N} \mathrm{CH}_{3} \mathrm{COOH}$ [5]). The complexes obtained could be decomposed even with $0.1 \mathrm{~N}$ acetic acid. The proteins were eliminated by Sevag's method [6], followed by treatment with trypsin and papain. The lipids were extracted with ether. The aqueous solutions were freeze-dried. The yields of the crude polysaccharide fractions are given in the table. The results of the determination of the contents of sulfur and uronic acids show that the mixtures contain an insignificant amount of acids and sulfated polysaccharides.

Characteristics of the Polysaccharide Fractions of Invertebrates of the Sea of Japan

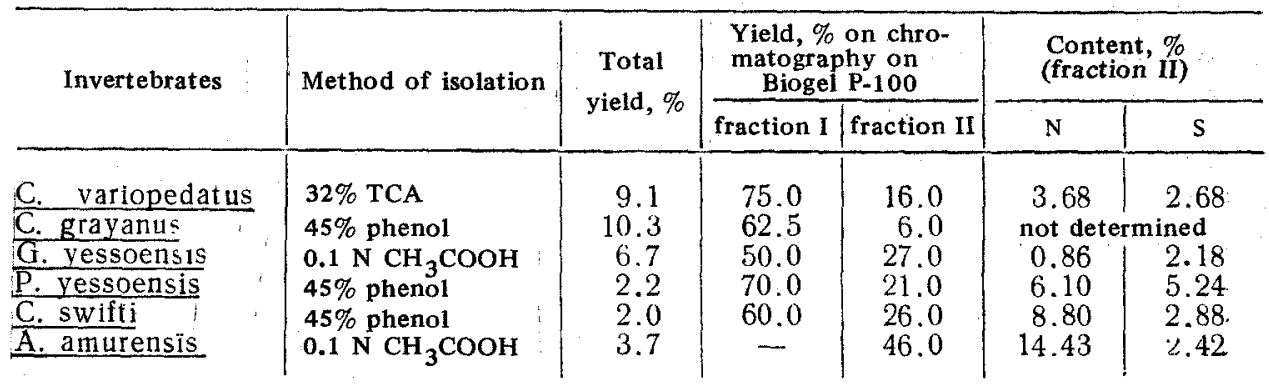
$10-18 \%$,

In the polysaccharide fractions of $G$. grayanus and $T$. aurantium there was $4-6 \%$ of glucosamine and in the others

When the polysaccharide fractions $(500 \mathrm{mg}$ ) from the invertebrates studied were subjected to preparative gel filtration on Biogel P-100 (Bio-Rad Laboratories, Richmond, Calif., USA) using a flow-through ultraviolet densitometer, they were each separated into two fractions (see table). The polysaccharide of the first fraction was characteristic for all the invertebrates and had properties similar to those of glycogen. It contained no sulfur or nitrogen and on complete hydrolysis with $2 \mathrm{~N}$ sulfuric acid gave only glucose. The results of chromatography on Biogel P-300 show its high molecular weight (above 300000 ). The polysaccharide showed the characteristic reaction with iodine. Its amylolysis gave glucose, maltose, and maltooligosaccharides.

The sulfur content of the second fraction shows the presence of sulfated polysaccharides in it.

The acid hydrolysates of these fractions from all the invertebrates mentioned, apart from $C$. grayanus and T. aurantium, were found to contain glucose, galactose, arabinose, xylose, rhamnose, and glucuronic acid.

\section{REFERENCES}

1. S. Hunt and F. R. Jevons, Biochem. J., 98, 522, 1966.

2. J. Doyle, Biochem, J., 103, 629, 1967.

3. O. Westphal, O. Lüderitz, and F. Bister, Naturforsch. , B. , 7, 148, 1952.

4. A. Boivín. I. Mesrobeanu, and L. Mesrobeanu, Compt. Rend. Soc. Biol., 114, 307, 1933.

5. W. T. J. Morgan and S. M. Partridge, Biochem. J., 34, 169, 1940.

6. M. S. Sevag, Biochem. Z., 273, 419, 1934. 